\title{
Screening of Alleged Medical Malpractice in Egypt (Fayoum Governorate)
}

\section{Marwa A Mwaheb*}

Department of Forensic Medicine and Clinical Toxicology, Fayoum University, Egypt

*Corresponding author: Marwa Ali Mwaheb, Department of Forensic Medicine and Clinical Toxicology, Faculty of Medicine, Fayoum University, Egypt, Tel: 0201006267354; E-mail: marwa.mwaheb@yahoo.com

Received date: September 01, 2016; Accepted date: October 04, 2016; Published date: October 14, 2016

Copyright: (c) 2016 Mwaheb MA. This is an open-access article distributed under the terms of the Creative Commons Attribution License, which permits unrestricted use, distribution, and reproduction in any medium, provided the original author and source are credited.

\begin{abstract}
Background and Objectives: Medical malpractice is a legal cause of action that occurs when a physician deviates from required substandard and causes deterioration, disability, harm or death to a patient. This study documented all the reported malpractice cases according to the forensic medicine authority in Fayoum Governrate in the in the course of regular and proper health service
\end{abstract}

Methods: All cases of medical malpractice claims of several medical specialties referred to the Forensic Medicine Authority, in 2012-2016 were checked $(n=55)$.

Results: The present study shows that $87.3 \%$ of the study group were adults, and $12.7 \%$ of them were children, $50.9 \%$ of them were males and $49.1 \%$ were females, and as regards to the place of residence, $47.3 \%$ of the victims were from urban places. The study has also pointed out that the majority of malpractices occurred in general hospitals $(67.3 \%)$, more than in clinics and private hospitals. The $40 \%$ of malpractice were complications of surgery, then $23.6 \%$ of them were due to negligence, then $21.8 \%$ of patients had medication errors, and the least percentage of $14.5 \%$ had forgotten gauze and the majority of malpractices occurred in obstetrics and gynaecology which represent $(36.4 \%)$ of the cases.

Conclusion: It is extremely essential to analyse the errors properly in order to get the medical malpractice under control to avoid incidence of litigation and to propose professional standards as well as accurate references in connection with medico-legal procedures.

Keywords: Forensic medicine; Malpractice; Fayoum; Egypt

\section{Introduction}

Medical malpractice has been an important social issue. Physicians have complained about the large number of malpractice claims and have insisted on legal reforms to reduce compensation for damage, whereas tort attorneys have argued that negligence claims are an effective way of compensating victims of negligence and of protecting the medical profession [1]. Medical Law is witnessing a huge change; significantly our attitude towards our health, health services, and the medical professions is changing. Physicians used to be considered above reproach and held in the highest respect. Recently, however doctors are no longer regarded as impeccable and beyond questioning [2].

Malpractice cases are used to refer to defective acts done during the process of providing healthcare services. In the words of the World Medical Organization, adopted at the 44th World Medical Assembly in 1992, medical malpractice has been looked upon as "the failure of the physician to provide the standard care for treatment of the patient's condition, a lack of skill, or negligence in providing care to the patient, which is the direct cause of harm to the patient" [3]. A person who alleges negligent medical malpractice must confirm four elements: (A) a duty of care owed by the physician, (B) the physician violated the applicable standard of care, (C) the person suffered a compensable injury, and (D) the injury was actually caused by the substandard conduct. Adopting these elements is central for a successful medical malpractice [4].

Physicians owe an ethical duty of care to those who request their treatment. This element is scarcely an issue in a malpractice case; because once a doctor agrees to treat a patient, he has a professional duty to provide competence care. Another main issue is that the plaintiff must show actual and compensable injuries, which are originally the result of the negligent care. Proof of injury may include not only the physical effects of the treatment performed by the physician but also psychological effects [5]. The average of medical malpractice allegation against healthcare professionals, healthcare centers, and general hospitals is continually increasing in recent years. The causes for this increase include continuous renewal in medical field due to progressive discovered new technology, rapid allocation of these innovations, and rise in education and knowledge of the public and media coverage [6].

\section{Aim of the Research}

The current research mainly aims to register the cases of medical negligence in Fayoum governorate and raising the awareness of the most common specialties in which negligence occurs. Another important goal is to explore the recurrence of these cases in both rural and urban areas and from which area most of the reported cases are located, rural or urban, and finally setting successful strategies to avoid the recurrence of these practices. 
Page 2 of 4

\section{Material and Methods}

All cases of medical malpractice claims referred to the Forensic Medicine Authority, between March 2012 and March 2016 were reviewed retrospectively and included into the present study $(\mathrm{n}=55)$. The cases were evaluated according to the following factors: age, gender, residence, complaints upon admission, healthcare institutions providing the treatment, failure or harm claimed to result from faulty care and treatment, their field of medical major, and the conclusions of the Forensic Medicine Authority.

\section{Statistical Analysis}

- Data were gathered and coded to facilitate data processing and double entered into Microsoft Access and data analysis was performed using SPSS software version 18 under windows 7;

- Simple descriptive analysis, in the form of numbers and percentages for qualitative data, was used together with arithmetic means as central tendency measurement, standard deviations as measure of dispersion for quantitative parametric data, and inferential statistic test for qualitative data;

- Chi square test was used to compare two of more than two qualitative sets;

- The level $\mathrm{P} \leq 0.05$ was considered the cut-off value for significance.

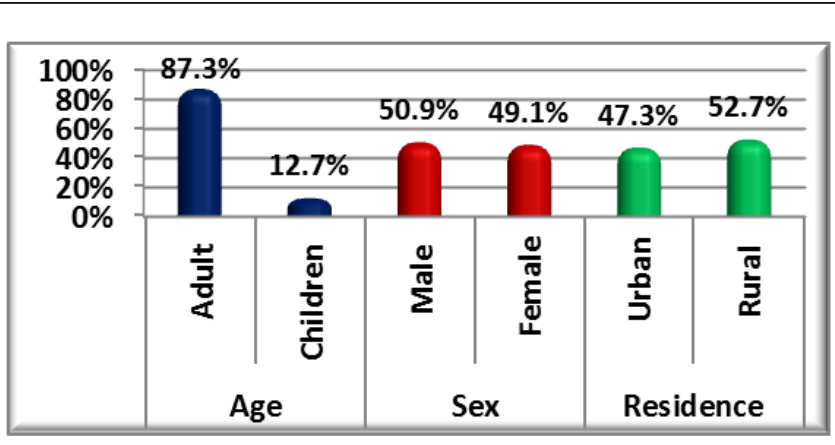

Figure 1: Frequency of demographic characters in study group.

\section{Results}

From the 55 cases with medical malpractice litigation from March 2012 to March 2016, 27 cases were females and 28 were males.

The present study shows that $87.3 \%$ of the study groups were adults and $12.7 \%$ of them were children less than 10 years old, $50.9 \%$ of them were males and $49.1 \%$ were females, and as regards the place of residence, $47.3 \%$ were from urban places as in Figure 1. This study shows that the majority of malpractices occurred in general hospitals $(67.3 \%)$, more than in clinics and private hospitals. The $40 \%$ of malpractice were complications of surgery, $23.6 \%$ of them were due to negligence, $21.8 \%$ of patients had medication errors and the least percentage of $14.5 \%$ had forgotten gauze as in Table 1.

This study also shows that the occurrence rate of malpractice throughout the years has increased from $16.4 \%$ in 2012 to $23.6 \%$ in 2013, then reached its peak $29.1 \%$ in 2014 , then started to decrease to $20 \%$ in 2015 and decreased further in 2016 to become $10.9 \%$ as in Figure 2.
The present study shows that the majority of malpractices occurred in obstetrics and gynaecology which represent (36.4\%) of the cases, followed by $(14.5 \%)$ for orthopaedic practice, then other majors as shown in Table 2 . The present study shows that there is no statistically significant difference with $\mathrm{p}$-value $>0.05$ between age group and residence as regards the types of medical malpractice in Table 3.

Conversely, there is a statistically significant difference with pvalue $<0.05$ in Figure 3 between gender and types of malpractice with high percentage of negligence (69.2\%), and medication error $(83.3 \%)$ among males , and high percentage of complication of surgery $(59.1 \%)$, and forgotten gauze (100\%) among females (Figures 1-3 and Tables $1-3)$.

\begin{tabular}{|l|l|l|}
\hline Variables & Number (n=55) & Frequency \% \\
\hline Place of malpractice & & \\
\hline General hospital & 37 & $67.30 \%$ \\
\hline Clinic & 10 & $18.20 \%$ \\
\hline Private hospital & 8 & $14.50 \%$ \\
\hline Type of malpractice & 22 & \\
\hline Complication of surgery & 13 & $40 \%$ \\
\hline Negligence & 12 & $23.60 \%$ \\
\hline Medication error & 8 & $14.50 \%$ \\
\hline Forgotten gauze & & $21.80 \%$ \\
\hline
\end{tabular}

Table 1: Types of medical malpractice accusations and distribution of expert opinion by the health centers.

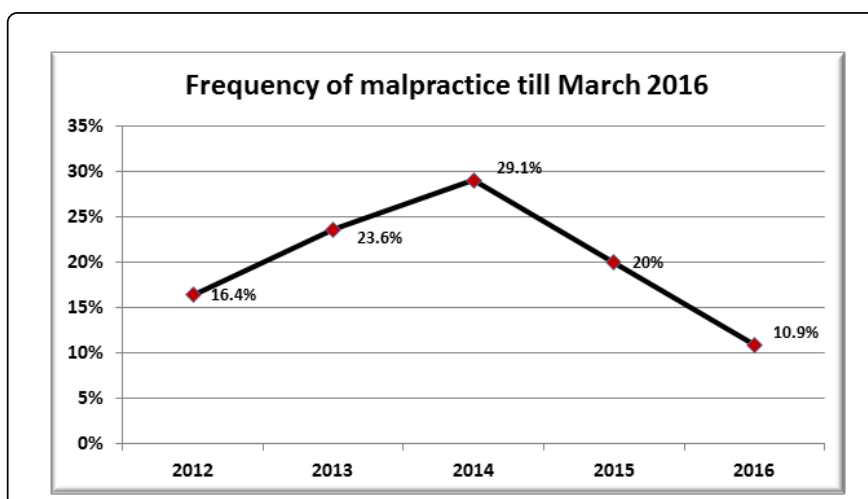

Figure 2: Distribution of cases according years.

\begin{tabular}{|l|l|l|}
\hline Variables & Number $(\mathbf{n = 5 5 )}$ & Frequency $\%$ \\
\hline Obstetrics and gynecology & 20 & $36.40 \%$ \\
\hline Orthopedic & 8 & $14.50 \%$ \\
\hline General surgery & 6 & $10.90 \%$ \\
\hline Urology & 5 & $9.10 \%$ \\
\hline Ophthalmology & 3 & $5.50 \%$ \\
\hline Anesthesia & 2 & $3.60 \%$ \\
\hline
\end{tabular}


Page 3 of 4

\begin{tabular}{|l|l|l|}
\hline Neurologist & 2 & $3.60 \%$ \\
\hline Andrology & 1 & $1.80 \%$ \\
\hline Burn & 1 & $1.80 \%$ \\
\hline Circumcision & 1 & $1.80 \%$ \\
\hline Dentistry & 1 & $1.80 \%$ \\
\hline Ear, nose, and throat & 1 & $1.80 \%$ \\
\hline Liver sample & 1 & $1.80 \%$ \\
\hline Nephrology & 1 & $1.80 \%$ \\
\hline Nursery & 1 & $1.80 \%$ \\
\hline Plastic surgery & 1 & $1.80 \%$ \\
\hline
\end{tabular}

Table 2: Proportion of physicians facing malpractice claim according to speciality.

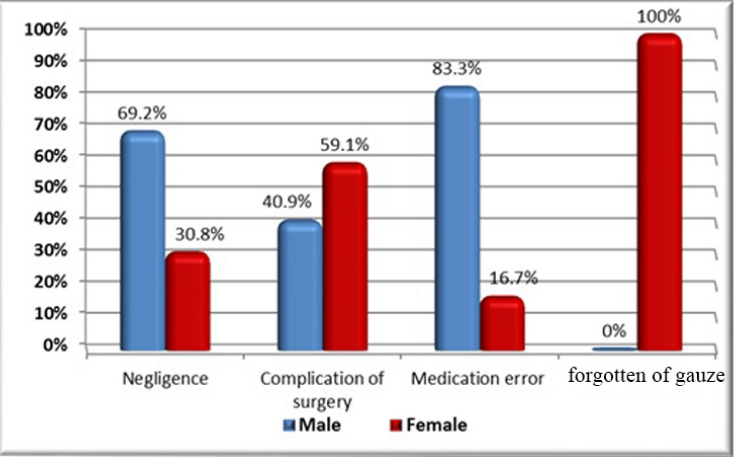

Figure 3: Relation between gender and type of medical malpractice causation.

\begin{tabular}{|c|c|c|c|c|c|}
\hline Variables & $\begin{array}{l}\text { Negligence } \\
(n=13)\end{array}$ & $\begin{array}{l}\text { Complication } \\
\text { of surgery } \\
(n=22)\end{array}$ & $\begin{array}{l}\text { Medication } \\
\text { error }(n=12)\end{array}$ & $\begin{array}{l}\text { Forgotten } \\
\text { of gauze } \\
(n=8)\end{array}$ & $p$-value \\
\hline \multicolumn{6}{|l|}{ Age } \\
\hline Adult & $10(76.9 \%)$ & $18(81.8 \%)$ & $12(100 \%)$ & $8(100 \%)$ & \multirow[b]{2}{*}{0.2} \\
\hline Children & $3(23.1 \%)$ & $4(18.2 \%)$ & $0(0 \%)$ & $0(0 \%)$ & \\
\hline \multicolumn{6}{|l|}{ Sex } \\
\hline Male & $9(69.2 \%)$ & 9 (40.9\%) & 10 (83.3\%) & $0(0 \%)$ & \multirow[b]{2}{*}{$0.001^{*}$} \\
\hline Female & $4(30.8 \%)$ & $13(59.1 \%)$ & $2(16.7 \%)$ & $8(100 \%)$ & \\
\hline \multicolumn{6}{|c|}{ Residence } \\
\hline Urban & $5(38.5 \%)$ & $7(31.8 \%)$ & $9(75 \%)$ & $5(62.5 \%)$ & \multirow[b]{2}{*}{0.07} \\
\hline Rural & $8(61.5 \%)$ & 15 (68.2\%) & $3(25 \%)$ & $3(37.5 \%)$ & \\
\hline
\end{tabular}

Table 3: Comparison of malpractice types in different demographic characters among study gender.

\section{Discussion}

A study conducted in Fayoum Governorate, Egypt, has shown that $87.3 \%$ of the study group were adults, and $12.7 \%$ of them were children, $50.9 \%$ of them were males and $49.1 \%$ were females, this agrees with the results of another study in Istanbul, Turkey, which reported that the three hundred and thirty cases with medical malpractice issue within a period of 11 years between 2000 and 2011, one hundred and sixty-five cases were females; one hundred and sixtyfour were males [7]. The most frequent medical malpractice issue has been against gynaecology and obstetrics (36.4\%), followed by orthopaedic (14.5\%) and general surgery (10\%), this agrees with the findings of the study in Istanbul which has documented that the most frequent medical malpractice claims have been against gynaecology and obstetrics (16.8\%), followed by general Surgery [7]. Another study in Saudi Arabia reported that gynaecology and obstetrics fields are in the lead with $27 \%$ followed by general surgery [8].

Also the present study shows that the occurrence rate of medical malpractice is common in general hospitals (67.3\%) against clinics (18.2\%) and private hospitals (14.5\%), this agrees with another study conducted in Italy which has reported that litigation has been against public institutions in $88 \%$ and against private clinics in $12 \%$ of the cases [9].

This study shows that the complication of a surgery makes up a great part of adverse events by " $40 \%$ ", then proceeded by negligence with $23.6 \%$, and this disagrees with another study in Egypt which showed that the negligence percentage was $31 \%$, followed by complication with surgical intervention with $15.4 \%$ [10]. The results also show that the frequency of malpractice throughout the years has increased from $16.4 \%$ in 2012 to $23.6 \%$ in 2013 , then reached its peak to $29.1 \%$ in 2014 , then started to decrease to $20 \%$ in 2015 and decreased again up till March 2016 to become 10.9\%. This result conforms to the findings of another research done in showed an increasing trend of medical error reporting from 2007 to 2013 [11].

In conclusion; the present study focuses on some elements of the problem and the systemic causes; such as malpractice, negligence and medical errors.

\section{References}

1. Madea B, Preuss J (2009) Medical malpractice as reflected by the forensic evaluation of 4450 autopsies. Forensic Sci Int 190: 58-66.

2. Kearns O, Mathuna, Scott (2009) For a discussion of the ethical issues raised by such self-diagnostic kits. In: Medical law and ethics (3rd edn), Oxford University Press, USA.

3. Madea B, Preuss J, Dettmeyer R (2007) Medical malpractice reproach in the emergency medication and in the emergency room. Notfall + Rettungsmedizin 8: 569-578.

4. Büken E, Ornek Büken N, Büken B (2004) Obstetric and gynecologic malpractice in Turkey: incidence, impact, causes and prevention. J Clin Forensic Med 11: 233-247.

5. Studdert DM, Mello MM, Gawande A, Gandhi TK, Kachalia A, et al. (2006) Claims, Errors, and Compensation Payments in Medical Malpractice Litigation. N Engl J Med 354: 2024-2033.

6. Pakiş I, Yaycı N, Karapirli M, Polat O (2008) The Role of Legal Autopsy inthe Investigation of Death Cases Due to Medical Malpractice. Türkiye Klinikleri J Med Sci 28: 30-39.

7. Yazıcı YA, Şen H, Aliustaoğlu S, Sezer Y, Ince CH (2015) Evaluation of the medical malpractice cases concluded in the General Assembly of Council of Forensic Medicine. Ulus Travma Acil Cerrahi Derg 21: 204-208. 
Citation: Mwaheb MA (2016) Screening of Alleged Medical Malpractice in Egypt (Fayoum Governorate). J Forensic Res 7: 341 . doi: 10.4172/2157-7145.1000341

Page 4 of 4

8. Samarkandi A (2006) Status of Medical Liability Claim in Saudi Arabia Ann Saudi Med 26: 87-91.

9. Nunzio DN, Alessandro DE, Luigi V, Luigi V, Stephen C, et al. (2004) Medical malpractice: a study of case histories by the Forensic Medicine Section of Bari. Am J Forensic Med Pathol 25: 141-144.

10. Hassan DAE, Shehab AM, Kotb H (2014) Alleged Medical Malpractice: A Retrospective Study of Forensic Evaluation of Cases in Cairo and Giza regions - Egypt (2009-2011). J Forensic Res 5: 239.
11. Ghaffar UB, Ahmed SM, Faraz A (2015) A Review of the Frequency of Medical Error in Saudi Arabia: An Emerging Concern. J evid based med healthc : 8692-8695. 